\title{
Diurnal variations in the composition of the faeces of pigs on diets containing chromium oxide
}

\author{
By J. H. MOORE \\ Department of Agricultural Chemistry, University of Reading
}

(Received 4 December 1956)

In a study of the intestinal absorption and excretion of calcium and phosphorus in the pig, which involved the analysis of the contents of the various sections of the alimentary tract at different times after feeding, Moore \& Tyler (1955a) showed that unabsorbed calcium and phosphorus passed along the tract at a more rapid rate than the bulk of the dry matter. It was apparent that such differential rates of passage of food constituents should result in diurnal variations in the composition of the faeces, which Moore \& Tyler (1955a) did actually demonstrate for calcium and phosphorus. They indicated also that the nature and extent of diurnal variations in faecal components depend upon the period of time between feeding.

During recent years diurnal variation in faecal composition has received attention from a number of workers interested in applying the insoluble-marker technique to digestibility determinations (e.g. Kane, Jacobson \& Moore, 1952), but most of the work has been done with ruminants and relatively little with monogastric animals.

This study was accordingly undertaken to determine the extent of the diurnal variations in the excretion of crude fibre, crude protein and chromium oxide when the oxide was added to the feed of pigs as an insoluble marker. It seemed desirable to investigate also the effect of different feeding treatments on diurnal variations in faecal composition.

\section{EXPERIMENTAL}

\section{Technique and procedure}

The pigs used in these experiments were of the same age and breed as those used in earlier studies (Moore \& Tyler, I955a-c) and were housed in metabolism cages and fed on a basal ration of the same composition as reported previously (Moore \& Tyler, I $955 \mathrm{a}$ ). To this basal ration were added $2 \% \mathrm{CaCO}_{3}, 0.5 \% \mathrm{NaCl}$ and $\mathrm{x} \%$ cod-liver oil.

Exp. I. The experimental diet was fed to two pigs (nos. 17 and 18 ) for a period of Io days before Exp. I began. During the experimental period A (days I-8) the pigs were fed twice daily at 9.30 a.m. and 3.30 p.m., and chromium oxide was included in the diet at the rate of $\mathrm{I} \%$. The basal ration, mineral supplements, cod-liver oil and $\mathrm{Cr}_{2} \mathrm{O}_{3}$ were weighed separately for each meal and mixed thoroughly with sufficient water to produce a feed of such consistency that there was no tendency for the $\mathrm{Cr}_{2} \mathrm{O}_{3}$ to settle out in the feeding trough. The pigs were fed slightly below appetite to ensure complete consumption of food. As soon as each meal had been consumed, adequate drinking water was placed in the feeding troughs. Faeces were collected quantitatively 
during the last 4 days of period A (days $5-8$ ), each voiding being collected separately from both pigs immediately after excretion and the time of excretion noted. Faeces excreted between 8.00 p.m. and 8.00 a.m. were collected together. This overnight fraction amounted to approximately $18.0 \%$ of the total daily output of faeces. During the experimental period B (days 9-16) the pigs were again fed twice daily but at 7.00 a.m. and 7.00 p.m., and the amount fed was increased (Table I). Faeces of each pig were collected separately from days $\mathrm{I} 3$ to $\mathrm{x} 6$ after the pigs had become accustomed to the different feeding schedule and to the increased food intake during a preliminary 4 days (days $9^{-1} 3$ ). Throughout period $\mathrm{C}$ (days $\mathrm{I}^{-24}$ ) the pigs were fed three times daily, at $7.00 \mathrm{a} . \mathrm{m} ., 1.00 \mathrm{p} . \mathrm{m}$. and 7.00 p.m., and faeces were collected separately at each voiding from days 2I to 24. During the collection periods of Exp. I, twelve to fourteen individual faecal excretions were collected daily. The treatments received by the pigs in Exp. $\mathrm{I}$ are summarized in Table $\mathrm{I}$.

\section{Table I. Exp. I. Feeding treatments of pigs}

\begin{tabular}{|c|c|c|c|c|c|}
\hline \multirow[b]{2}{*}{ Period } & \multirow[b]{2}{*}{ Pig no. } & \multicolumn{2}{|c|}{ Weight of basal ration } & \multicolumn{2}{|c|}{ Weight of $\mathrm{Cr}_{2} \mathrm{O}_{3}$ fed } \\
\hline & & $\begin{array}{c}\text { Total } \\
\text { (g/day) } \\
800 \\
1200\end{array}$ & $\begin{array}{c}\text { Per feed } \\
(\mathrm{g}) \\
400 \\
500\end{array}$ & $\begin{array}{c}\text { Total } \\
\text { (g/day) } \\
8 \cdot 0 \\
12 \cdot 0\end{array}$ & $\begin{array}{c}\text { Per feed } \\
(\mathrm{g}) \\
4 \cdot 0 \\
6.0\end{array}$ \\
\hline $\begin{array}{l}\mathrm{B} \text { (days } 9-\mathrm{I} 6 \text {; pigs fed at } 7.00 \text { a.m. } \\
\text { and } 7 \text { p.m.) }\end{array}$ & $\begin{array}{l}\text { I7 } \\
\text { I } 8\end{array}$ & $\begin{array}{l}1400 \\
1400\end{array}$ & $\begin{array}{l}700 \\
700\end{array}$ & $\begin{array}{l}14 \cdot 0 \\
14 \cdot 0\end{array}$ & $\begin{array}{l}7 \cdot 0 \\
7 \cdot 0\end{array}$ \\
\hline $\begin{array}{l}\mathrm{C} \text { (days } 17-24 ; \text { pigs fed at } 7.00 \text { a.m., } \\
\text { I.00 p.m. and } 7.00 \text { p.m.) }\end{array}$ & $\begin{array}{l}17 \\
18\end{array}$ & $\begin{array}{l}1800 \\
1800\end{array}$ & $\begin{array}{l}600 \\
600\end{array}$ & $\begin{array}{l}18 \cdot 0 \\
18 \cdot 0\end{array}$ & $\begin{array}{l}6 \cdot 0 \\
6 \cdot 0\end{array}$ \\
\hline
\end{tabular}

Exp. 2. The results of Exp. I showed that $\mathrm{Cr}_{2} \mathrm{O}_{3}$ was excreted at peak concentration in the faeces at various times during the day and it appeared that the $\mathrm{Cr}_{2} \mathrm{O}_{3}$ of each peak was derived from the $\mathrm{Cr}_{2} \mathrm{O}_{3}$ of a particular meal. Exp. 2 was performed to discover from which meal containing $\mathrm{Cr}_{2} \mathrm{O}_{3}$ a particular peak was derived.

The experimental diet was fed to two pigs (nos. I9 and 20) twice daily at 9.30 a.m. and $3.30 \mathrm{p} . \mathrm{m}$. and a constant daily food intake was maintained throughout the experiment. After the pigs had received this diet for Io days, $\mathrm{I} \% \mathrm{Cr}_{2} \mathrm{O}_{3}$ was included in the 9.30 a.m. meal of both pigs on the IIth day. Quantitative collection of faeces, as described in Exp. I, was begun immediately and continued until $\mathrm{Cr}_{2} \mathrm{O}_{3}$ could no longer be estimated quantitatively in the faeces.

This procedure was then repeated ro days later with the exception that both pigs received the single dose of $\mathrm{Cr}_{2} \mathrm{O}_{3}$ in the $3.30 \mathrm{p} . \mathrm{m}$. meal.

Exp. 3. To obtain further information about the cause of the diurnal variations in faecal composition that occurred in Exps. I and 2, a third experiment was done in which gastro-intestinal contents were analysed.

The experimental diet was fed to two pigs (nos. $2 \mathrm{I}$ and 22) twice daily at $9.30 \mathrm{a} . \mathrm{m}$. and 3.30 p.m. for Io days. On the IIth day $1 \% \mathrm{Cr}_{2} \mathrm{O}_{3}$ was included in the $9.30 \mathrm{a}$.m. meal of each pig. Both pigs were killed by injection of Nembutal (Abbott Laboratories $\mathrm{Ltd}$ ) $4 \mathrm{~h}$ after feeding. The gastro-intestinal tracts were divided into the sections described previously by Moore \& Tyler (1955a) and the contents of each section were removed as completely as possible. 


\section{Treatment of materials and methods of analysis}

The faeces obtained in Exps. $\mathrm{I}$ and 2 and the gastro-intestinal contents from Exp. 3 were dried at $100-105^{\circ}$ and weighed. The pigs left no food residues in any of the experiments. All material was ground in a Wiley mill before analysis for $\mathrm{Cr}_{2} \mathrm{O}_{3}$, crude protein and crude fibre. $\mathrm{Cr}_{2} \mathrm{O}_{3}$ was determined by the method of Christian \& Coup (I954), and crude protein and crude fibre by the usual methods (Association of Official Agricultural Chemists, 1950).

\section{RESULTS}

Exp. r. When the percentage of the determined constituents in the dry matter of the faeces was plotted against time of excretion during each of the 4 -day collection
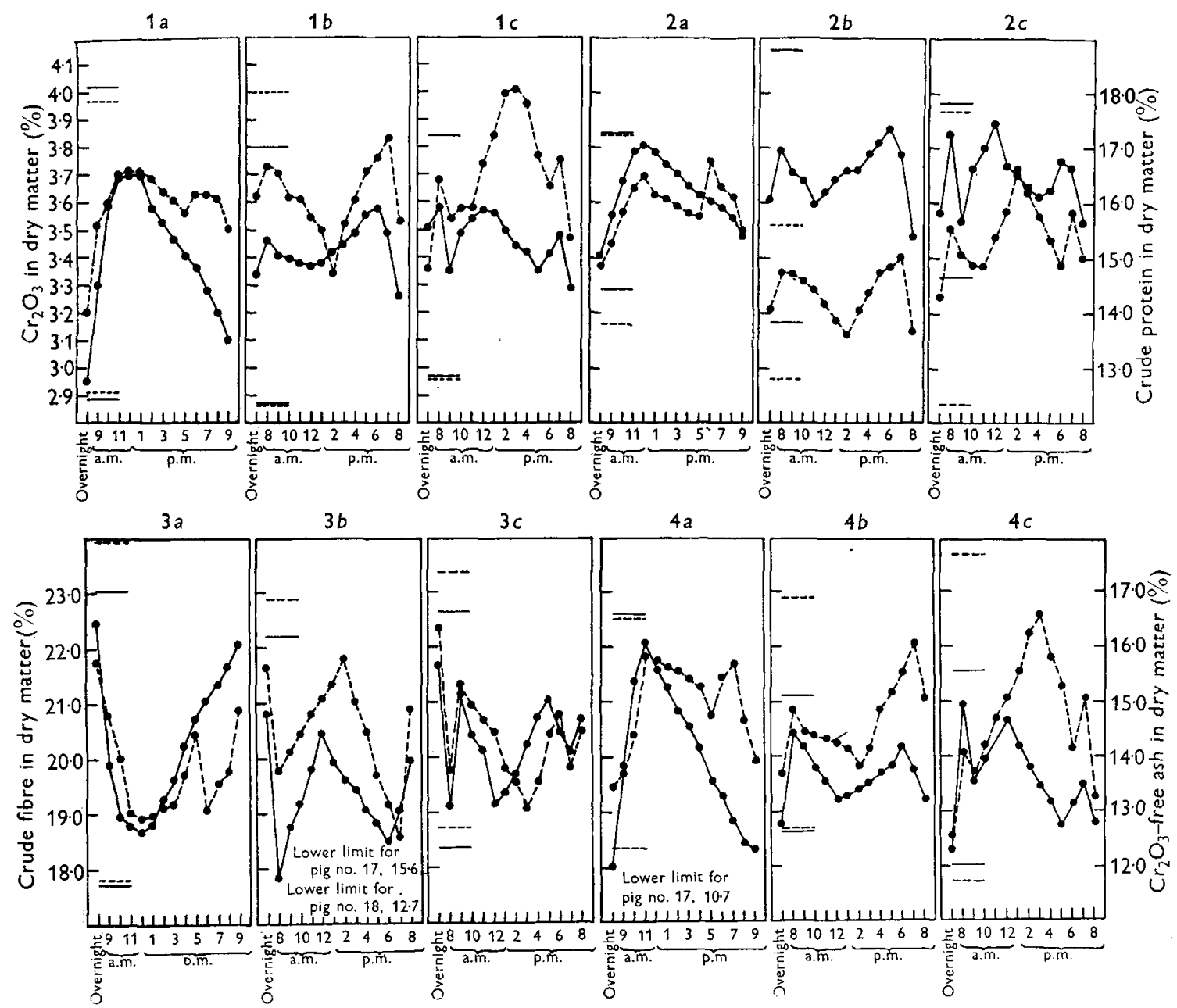

Fig. I. Exp. I. Diurnal variations in the percentage of (1) $\mathrm{Cr}_{2} \mathrm{O}_{3},(2)$ crude protein, (3) crude fibre, and (4) $\mathrm{Cr}_{2} \mathrm{O}_{3}$-free ash in the dry matter excreted by pigs nos. 17 and 18 during periods $\mathrm{A}(a), \mathrm{B}(b)$ and $\mathrm{C}(c)$. The horizontal lines show the limits between which the concentration of $\mathrm{Cr}_{2} \mathrm{O}_{3}$, crude protein, crude fibre and $\mathrm{Cr}_{2} \mathrm{O}_{3}$-free ash varied during each 4-day period. ,--- , pig no. 18. 
periods it was immediately obvious that the daily excretion patterns of the various faecal components were very characteristic for each pig on a particular feeding treatment. However, the complete results of Exp. 1 are too extensive to present in detail and the following method of expressing the data was adopted. Since the faecalexcretion patterns of $\mathrm{Cr}_{2} \mathrm{O}_{3}$ for pig no. 18 on days $5,6,7$ and 8 , for example, were very similar it was possible to obtain from the daily excretion curves a mean value for the percentage of $\mathrm{Cr}_{2} \mathrm{O}_{3}$ in the faeces of the overnight collection and at hourly intervals from 9.00 a.m. to 9.00 p.m. These mean values were then plotted as in Fig. I ( $\mathrm{r} a$ ), and a composite excretion curve for $\mathrm{Cr}_{2} \mathrm{O}_{3}$ representing the whole 4-day collection period was obtained. This treatment was applied to all the values obtained in Exp. I and the excretion curves derived for the determined faecal components are given in Fig. I. In view of the fact that there were day-to-day differences in the time that faeces of corresponding composition were excreted by each pig during the collection periods, the composite excretion curves do not illustrate the maximum variation in composition that was actually obtained. Accordingly, horizontal lines are included in the figure to show the limits between which the concentration of a particular faecal constituent varied during each 4-day period. Variations in the percentage of $\mathrm{Cr}_{2} \mathrm{O}_{3}$ in the dry matter of the faeces excreted at different times of the day by pigs nos. 17 and $\mathrm{I} 8$ during the last 4 days of experimental periods $\mathrm{A}$ (9.30 a.m. and $3.30 \mathrm{p} . \mathrm{m}$. feeding), B (7.00 a.m. and 7.00 p.m. feeding) and C (7.00 a.m., r.00 p.m. and 7.00 p.m. feeding) are shown in Fig. I ( $\mathrm{I} a, \mathrm{I} b$ and $\mathrm{I} c$ respectively).

When the pigs were fed at 9.30 a.m. and 3.30 p.m. (Fig. I (I $a$ )) two distinct peaks of $\mathrm{Cr}_{2} \mathrm{O}_{3}$ excretion (at about $\mathrm{I} 2$ noon and 7 p.m.) were shown daily by pig no. 18 , but only one (at about $\mathrm{I2}$ noon) by pig no. 17 . Low concentrations of $\mathrm{Cr}_{2} \mathrm{O}_{3}$ occurred in the overnight collections of faeces from both pigs. During the last 4 days of period $\mathrm{B}$ two peaks of $\mathrm{Cr}_{2} \mathrm{O}_{3}$ concentration appeared each day in the faeces of both pigs. The first peak occurred at $8.00 \mathrm{a} . \mathrm{m}$. with both pigs and the second at $6.00 \mathrm{p} . \mathrm{m}$. with pig no. I7 and at 7.00 p.m. with pig no. I8. As in period A, low concentrations of $\mathrm{Cr}_{2} \mathrm{O}_{3}$ were observed in the overnight or late evening collections of faeces. Feeding the pigs three times per day resulted in the appearance of three daily peaks of $\mathrm{Cr}_{2} \mathrm{O}_{3}$ excretion in the faeces. The first and third peaks occurred at 8.00 a.m. and 7.00 p.m. respectively with both pigs, whereas the second peak occurred at 12.00 noon with pig no. 17 and at $3.00 \mathrm{p}$.m. with pig no. I8. Faeces excreted late in the evening or overnight again were low in $\mathrm{Cr}_{2} \mathrm{O}_{3}$. It is interesting to note that the first and third peaks of $\mathrm{Cr}_{2} \mathrm{O}_{3}$ concentrations in the faeces of the pigs during period $\mathrm{C}$ occurred at about the same time each day as the two daily peaks observed in period $\mathrm{B}$.

Since the collection of faeces during the experiment was quantitative it was possible to calculate the percentage of $\mathrm{Cr}_{2} \mathrm{O}_{3}$ recovered in the faeces during each collection period. From the results in Table 2 it can be seen that the recovery of $\mathrm{Cr}_{2} \mathrm{O}_{3}$ in the faeces was consistently low in all periods.

Variations in the percentage of crude protein in the dry matter of the faeces excreted at different times of the day by pigs nos. $\mathrm{I} 7$ and $\mathrm{I} 8$ during the last 4 days of experimental periods A, B and C are shown in Fig. I ( $2 a, 2 b$ and $2 c$ respectively). When Fig. I (I) is compared with Fig. I (2) it is clear that the excretion patterns of 
$\mathrm{Cr}_{2} \mathrm{O}_{3}$ and protein corresponded fairly closely. Thus, in period A there was one daily peak of concentration of crude protein with pig no. 17 and two with pig no. 18 , whereas crude protein was excreted at high concentration twice daily in the faeces of both pigs during period $\mathrm{B}$. When the pigs were fed three times daily (period C) three peaks of crude-protein concentration were observed in the faeces both pigs excreted during each day.

Table 2. Exp. I. Percentage recovery of ingested $\mathrm{Cr}_{2} \mathrm{O}_{3}$ in the faeces excreted during the collection periods

Collection
period
(days)
$5-8$
$53-16$
$21-24$

\begin{tabular}{|c|c|}
\hline \multicolumn{2}{|c|}{ Pig no. } \\
\hline 17 & I 8 \\
\hline $\begin{array}{l}82 \cdot 5 \\
80^{\circ} 0\end{array}$ & $\begin{array}{l}85 \cdot 4 \\
81 \cdot 0\end{array}$ \\
\hline $77 \cdot 9$ & $86 \cdot 3$ \\
\hline
\end{tabular}

Sometimes the relationship between the concentration of crude protein and $\mathrm{Cr}_{2} \mathrm{O}_{3}$ in the faeces was very marked, as can be judged from Fig. $2 a$ in which the percentage of crude protein in the dry matter has been plotted against the percentage of $\mathrm{Cr}_{2} \mathrm{O}_{3}$ determined in the individual samples of faeces collected on day 24 from pig no. 17 .

Variations in the percentage of crude fibre in the dry matter of the faeces excreted at different times of the day by pigs nos. 17 and 18 during the last 4 days of experimental periods $\mathrm{A}-\mathrm{C}$ are shown in Fig. I ( $3 a, 3 b$ and $3 c$ respectively). Comparison of Fig. I (I) with Fig. I (3) indicates that variations in the percentage of crude fibre in the dry matter of the faeces were opposite to those observed with $\mathrm{Cr}_{2} \mathrm{O}_{3}$ and crude protein. The crude-fibre percentage in the dry matter of the faeces of both pigs during period $\mathrm{A}$ was highest in the late evening or overnight excretions, i.e. when the concentrations of $\mathrm{Cr}_{2} \mathrm{O}_{3}$ and crude protein were lowest. A second peak of crude-fibre excretion in the faeces of pig no. I 8 could be distinguished in the afternoon during this period. When the pigs were fed at $7.00 \mathrm{a} . \mathrm{m}$. and $7.00 \mathrm{p} . \mathrm{m}$. the faeces excreted late in the evening or overnight and in the middle of the day contained the highest percentage of crude fibre in the dry matter. Three peaks of crude-fibre excretion could be recognized in the faeces excreted by the pigs during period $\mathrm{C}$ but these peaks again occurred in the faeces low in $\mathrm{Cr}_{2} \mathrm{O}_{3}$ and crude protein. The inverse relationship between the crude fibre and $\mathrm{Cr}_{2} \mathrm{O}_{3}$ contents of the faeces was particularly clear on certain days, as may be observed from Fig. $2 b$ in which the percentage of crude fibre has been plotted against the percentage of $\mathrm{Cr}_{2} \mathrm{O}_{3}$ in the dry matter of the samples of faeces collected on day 13 from pig no. I7.

Values were available also for the percentage of total ash in the dry matter of the faeces since the determination of $\mathrm{Cr}_{2} \mathrm{O}_{3}$ by the method of Christian \& Coup (1954) involves the preliminary ashing of the dried samples of faeces. The weight of $\mathrm{Cr}_{2} \mathrm{O}_{3}$ determined in each sample of faeces was subtracted from the weight of total ash, giving a value for $\mathrm{Cr}_{2} \mathrm{O}_{3}$-free ash. Variations in this value for faeces excreted at different times of the day by pigs nos. 17 and 18 during the last 4 days of experimental periods $\mathrm{A}, \mathrm{B}$ and $\mathrm{C}$ are shown in Fig. $\mathrm{I}$ (4). 
There was a fairly close relationship between the percentage of $\mathrm{Cr}_{2} \mathrm{O}_{3}$-free ash and percentage of $\mathrm{Cr}_{2} \mathrm{O}_{3}$ in the dry matter of the faeces. This relationship is shown in Fig. $2 c$ in which the percentage of $\mathrm{Cr}_{2} \mathrm{O}_{3}$-free ash has been plotted against the percentage of $\mathrm{Cr}_{2} \mathrm{O}_{3}$ in the dry matter of the samples of faeces collected on day 6 from pig no. 17 .
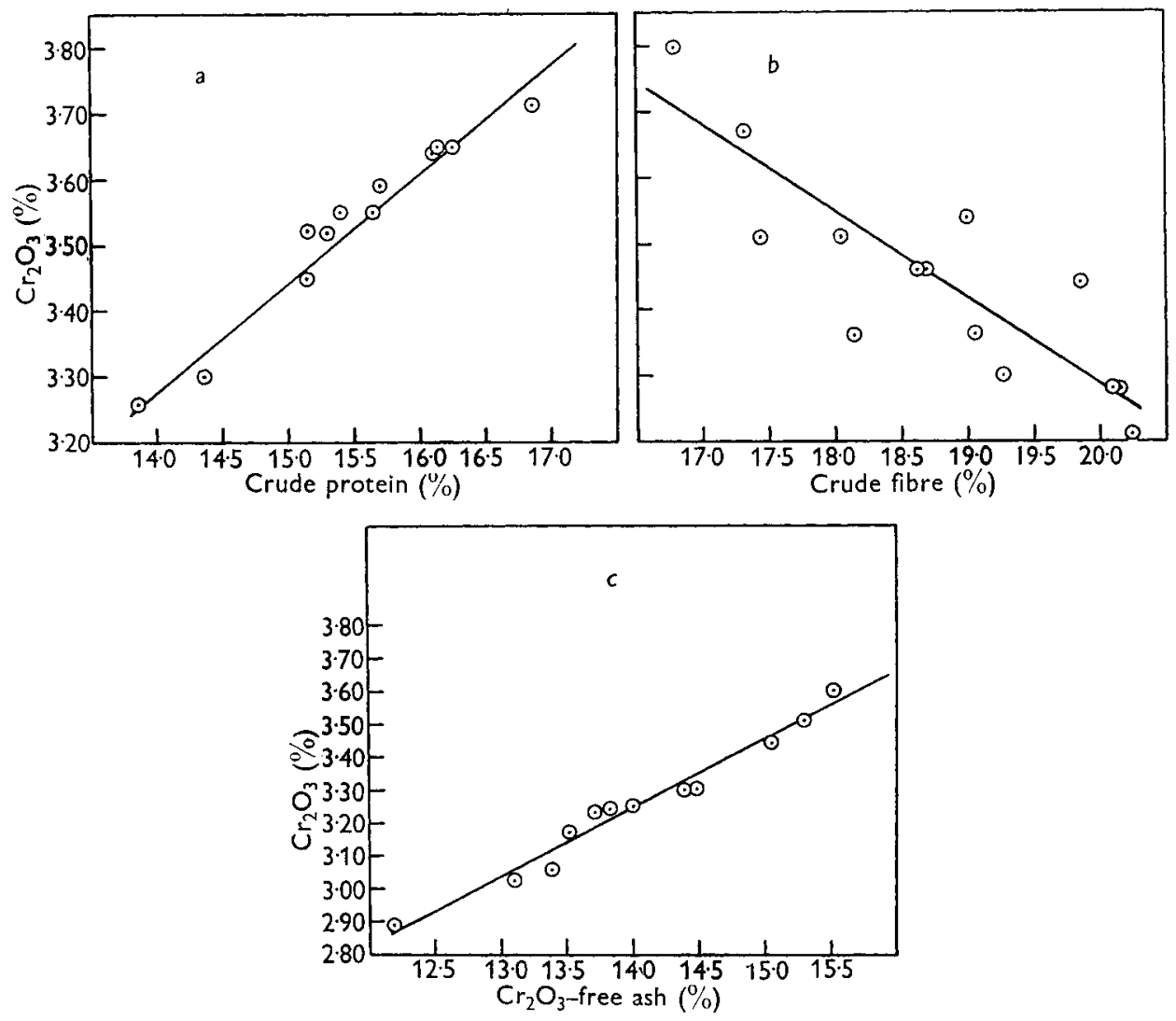

Fig. 2. Exp. I. Relationship between $\mathrm{Cr}_{2} \mathrm{O}_{3}(Y)$ and $(a)$ crude protein $\left(X_{a}\right),(b)$ crude fibre $\left(X_{b}\right)$ and (c) $\mathrm{Cr}_{2} \mathrm{O}_{3}$-free ash $\left(X_{e}\right)$, in the dry matter of the faeces excreted by pig no. 17 on day $24, \mathrm{r}_{3}$ and 6 , respectively. $(a)$ Correlation coefficient, 0.9846 ; significance, $P<0.001$; regression equation, $Y=0.167 X_{a}+0.938$. (b) Correlation coefficient, -0.8856 ; significance, $P<0.001$; regression equation, $Y=-0.13 \mathrm{I} X_{b}-5.911$. (c) Correlation coefficient, 0.9837 ; significance, $P<0.00 \mathrm{r}$; regression equation, $Y=0.208 X_{c}+0.328$.

Exp. 2. Variations in the percentage of $\mathrm{Cr}_{2} \mathrm{O}_{3}$ in the dry matter of the faeces excreted by pigs nos. 19 and 20 after they had received one dose of $\mathrm{Cr}_{2} \mathrm{O}_{3}$ in the morning meal (9.30 a.m.) are shown in Fig. $3 a$. The first detectable quantities of $\mathrm{Cr}_{2} \mathrm{O}_{3}$ appeared in the faeces of both pigs a little over $6 \mathrm{~h}$ after feeding. The concentration of $\mathrm{Cr}_{2} \mathrm{O}_{3}$ in the faeces reached a maximum $23 \mathrm{~h}$ after the meal containing $\mathrm{Cr}_{2} \mathrm{O}_{3}$ in pig no. 19 and $24 \mathrm{~h}$ after it in pig no. 20. In addition to the main peak of $\mathrm{Cr}_{2} \mathrm{O}_{3}$ in the early morning faeces excreted on day $\mathrm{I} 2 \mathrm{a}$ smaller peak occurred in the faeces excreted by pig no. 19 at 5.50 p.m. and in the faeces excreted by pig no. 20 at 7.00 p.m. on the same day. Analysis of faeces excreted $3^{6 \mathrm{~h}}$ after the $\mathrm{Cr}_{2} \mathrm{O}_{3}$ had been given in the morning feed 
was discontinued as after that time the faeces did not contain enough $\mathrm{Cr}_{2} \mathrm{O}_{3}$ for measurement by the method used.

Variations in the percentage of $\mathrm{Cr}_{2} \mathrm{O}_{3}$ in the dry matter of the faeces excreted by pigs nos. I9 and 20 after they had received one dose of $\mathrm{Cr}_{2} \mathrm{O}_{3}$ in the afternoon (3.30 p.m.) meal are shown in Fig. 3 . Since faecal production during the overnight period was much less than during the day, the first $\mathrm{Cr}_{2} \mathrm{O}_{3}$ to be excreted took longer (i.e. about $17 \mathrm{~h}$ ) to appear when the single dose of $\mathrm{Cr}_{2} \mathrm{O}_{3}$ was administered in the

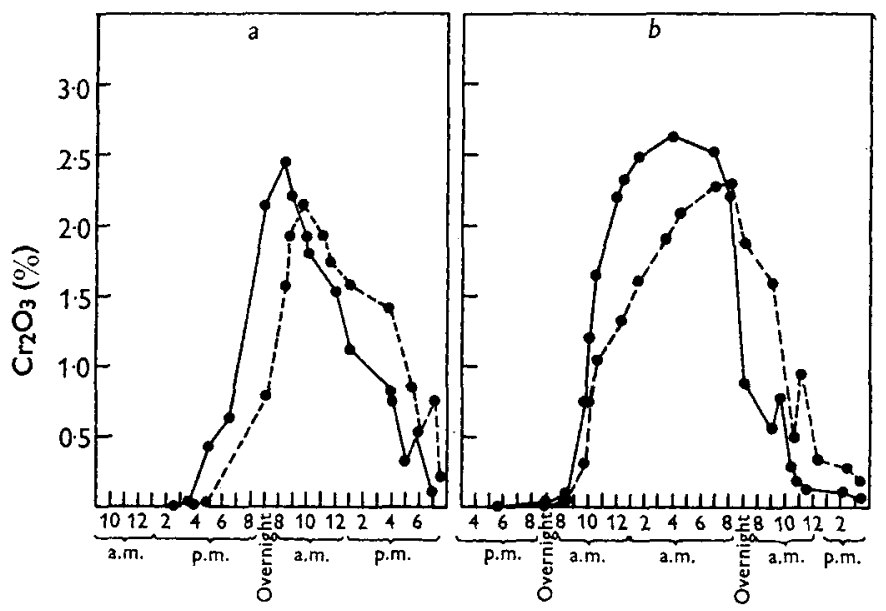

Fig. 3. Exp. 2. Variations in the percentage of $\mathrm{Cr}_{2} \mathrm{O}_{3}$ in the dry matter of the faeces excreted by pigs nos. 19 and 20 after receiving single doses of $\mathrm{Cr}_{2} \mathrm{O}_{3}$ in $(a)$ the $9.30 \mathrm{a.m}$. feed and $(b)$ the $3.30 \mathrm{p} . \mathrm{m}$. feed. - - , pig no. 19; - - -, pig no. 20 .

afternoon than when it was administered in the morning feed. With pigs nos. 19 and 20 highest $\mathrm{Cr}_{2} \mathrm{O}_{3}$ concentrations occurred in the faeces 24 and $29 \mathrm{~h}$ after the meal containing the $\mathrm{Cr}_{2} \mathrm{O}_{3}$ had been given. The small peak of $\mathrm{Cr}_{2} \mathrm{O}_{3}$ excretion which occurred on day 23 in the faeces excreted at $9.30 \mathrm{a} . \mathrm{m}$. by pig no. 19 and at $10.30 \mathrm{a} . \mathrm{m}$. by pig no. 20 should be noted. The faeces of both pigs contained only traces of $\mathrm{Cr}_{2} \mathrm{O}_{3}$ $48 \mathrm{~h}$ after the single dose of $\mathrm{Cr}_{2} \mathrm{O}_{3}$ had been given in the afternoon meal. During the collection periods of Exp. 2 a mean of $65 \%$ of the ingested $\mathrm{Cr}_{2} \mathrm{O}_{3}$ was recovered in the faeces.

Exp. 3. The percentages of $\mathrm{Cr}_{2} \mathrm{O}_{3}$, crude protein and crude fibre in the dry matter of the feed and of the contents of the various sections of the gastro-intestinal tract of pigs nos. $2 \mathrm{I}$ and 22 are given in Table 3. Comparison of the percentages of $\mathrm{Cr}_{2} \mathrm{O}_{3}$ in the feed and in the contents of the first and second sections of the stomach indicated that the rates of removal of $\mathrm{Cr}_{2} \mathrm{O}_{3}$ and dry matter from the stomach into the small intestine were about the same during the first $4 \mathrm{~h}$ of digestion. (For a discussion of the interpretation of analysis of gastro-intestinal contents see Moore \& Tyler, 1955 a.)

The gradual increase in percentage of $\mathrm{Cr}_{2} \mathrm{O}_{3}$ in the dry matter of the contents along the small intestine from section $\mathrm{I}$ to section 5 (Table 3 ) was due to general absorption of dry matter. Material in the large intestine would consist of a mixture of residues of the 3.30 p.m. meal (containing no $\mathrm{Cr}_{2} \mathrm{O}_{3}$ ) of the previous day and of residues of the 
meal containing $\mathrm{Cr}_{2} \mathrm{O}_{3}$ consumed $4 \mathrm{~h}$ before the pigs were killed (Moore, I952), and as a result the percentage of $\mathrm{Cr}_{2} \mathrm{O}_{3}$ in the dry matter of the contents of the large intestine was considerably lower than in the contents of the fifth section of the small intestine. Although no $\mathrm{Cr}_{2} \mathrm{O}_{3}$ was detected in the contents of the rectum the results obtained for the contents of the remainder of the large intestine suggested that $4 \mathrm{~h}$ after feeding the first food residues derived from the last meal had reached the anterior portion of the second section of the colon. This finding was consistent with the observation made in Exp. 2 that the first $\mathrm{Cr}_{2} \mathrm{O}_{3}$ appeared in the faeces $6 \mathrm{~h}$ after it had been administered in the 9.30 a.m. meal. It may also be concluded from Exp. 2 that the food residues of highest $\mathrm{Cr}_{2} \mathrm{O}_{3}$ content, present in the fifth section of the small intestine of pigs nos. $2 \mathrm{I}$ and $22,4 \mathrm{~h}$ after feeding, would normally have been excreted in the faeces about $24 \mathrm{~h}$ later.

Table 3. Exp. 3. Composition of the feed and gastro-intestinal contents of pigs nos. $2 \mathrm{I}$ and 22

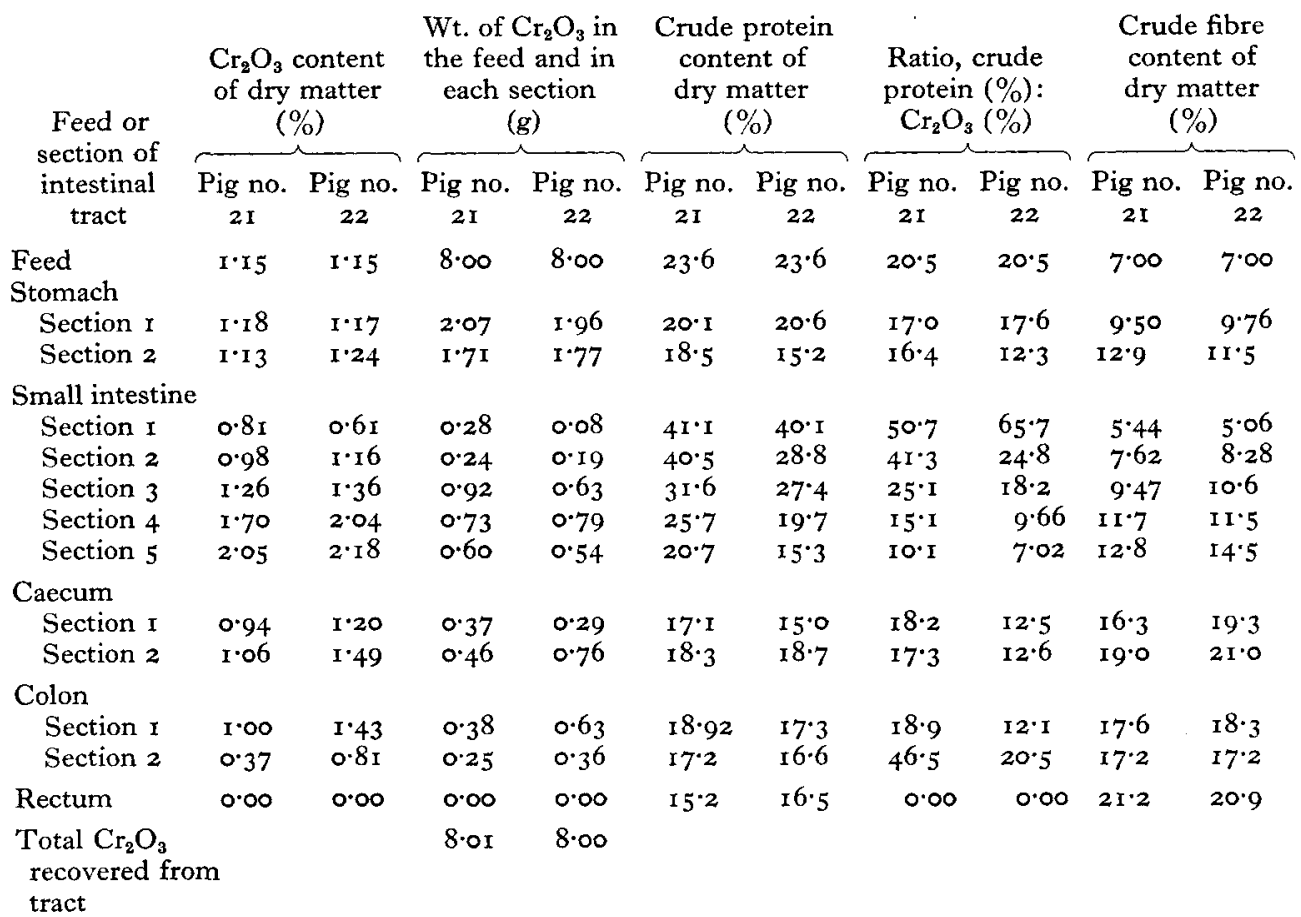

The division of stomach and intestine into sections was that described by Moore \& Tyler (1955 $a$ ).

The total weights of $\mathrm{Cr}_{2} \mathrm{O}_{3}$ recovered from each section and from the whole of the gastro-intestinal tracts of pigs nos. $2 \mathrm{I}$ and 22 are given in Table 3 . In both pigs the recovery of dietary $\mathrm{Cr}_{2} \mathrm{O}_{3}$ from the gastro-intestinal contents amounted to $100 \%$.

The percentage of protein in the dry matter of the contents of the first and second sections of the stomach was lower than in the food, and it would appear therefore that nitrogenous substances were removed from the stomach more rapidly than the bulk 
of the dry matter. As a result, and also from the probable addition of nitrogencontaining compounds in the pancreatic and bile juices, a particularly high value was observed for the percentage of crude protein in the dry matter of the contents of the first section of the small intestine. Boyne, Campbell, Davidson \& Cuthbertson (1956) have recently reported on the addition of nitrogenous material to the proximal small intestine of sheep. Absorption of the products of protein digestion was evident from the progressive decrease in the percentage of crude protein in the dry matter of the contents of the small intestine from section $\mathrm{I}$ to section 5. The absorption of nitrogenous material was even more noticeable when the ratios of crude protein to $\mathrm{Cr}_{2} \mathrm{O}_{3}$ (Table 3 ) were considered. With these ratios complications due to the absorption of non-nitrogenous components of the diet could be eliminated.

The crude-protein concentration in the contents of the various sections of the large intestine of pigs nos. $2 \mathrm{I}$ and 22 suggested that faeces of low protein content would be excreted some time in the afternoon, whereas faeces of higher protein content would be excreted in the evening. This was actually found to be so for pig no. 18 during period A of Exp. r.

Since the percentage of crude fibre in the dry matter of both sections of the stomach of pigs nos. 21 and 22 was higher than in the feed it may be concluded that crude fibre left the stomach at a much slower rate than the bulk of the dry matter during the first $4 \mathrm{~h}$ of digestion. Consequently the percentage of crude fibre in the dry matter of the first section of the small intestine was particularly low. As the digestion and absorption of the fat, carbohydrate and protein components of the diet proceeded, the percentage of crude fibre in the dry matter of the contents of the small intestine increased gradually from section I to section 5 . The values for the percentage of crude fibre in the dry matter of the contents of the large intestine seemed to indicate that faeces high in crude fibre would be excreted in the afternoon, as was in fact observed for pig no. I 8 during period $A$ of Exp. I.

\section{DISCUSSION}

Although the main purpose of the experiments reported in this communication was to investigate the cause and extent of diurnal variation in the faecal excretion of $\mathrm{Cr}_{2} \mathrm{O}_{3}$, crude protein and crude fibre in the pig, one of the most significant findings was the remarkably low recovery of dietary $\mathrm{Cr}_{2} \mathrm{O}_{3}$ excreted in the faeces during the collection periods of Exp. I. Each 4 -day collection period was preceded by a preliminary feeding period of 4 days which should have been adequate according to the results of Clawson, Reid, Sheffy \& Willman (I955), who found that the $\mathrm{Cr}_{2} \mathrm{O}_{3}$ concentration in the faeces of pigs attained equilibrium with that of the diet in $3^{-4}$ days. A collection period of 4 days should also have been sufficient to ensure an accurate estimate of the recovery in the faeces of ingested $\mathrm{Cr}_{2} \mathrm{O}_{3}$. Nevertheless, consistently low recoveries varying from 78 to $86 \%$ were obtained for each 4 -day period for both pigs. Low recoveries of dietary $\mathrm{Cr}_{2} \mathrm{O}_{3}$ in the faeces have been reported previously in the literature by a number of workers (Anderson \& Winther, 1934; Barnicoat, r945; Dansky \& Hill, I952; Kreula, I947; Schneider, I955; Mueller, I956), and various suggestions have 
been made to account for them. Certain of these suggestions may have a bearing on the results obtained in the present work.

Losses of $\mathrm{Cr}_{2} \mathrm{O}_{3}$ through errors in chemical estimation would appear to be most unlikely since the method of Christian \& Coup (1954) has been thoroughly tested not only in this laboratory but also in collaboration with the Biochemistry and Animal Nutrition Department of the Grassland Research Institute, Hurley, and has been found to be satisfactory. The fact that $100 \%$ recovery of $\mathrm{Cr}_{2} \mathrm{O}_{3}$ was obtained in Exp. 3 also points to the adequacy of the method of analysis.

The method of feeding the pigs in Exps. I-3 would seem to preclude any loss of indicator in the feed container such as was observed by Heller, Breedlove \& Likely (1928) when they used iron oxide $\left(\mathrm{Fe}_{2} \mathrm{O}_{3}\right)$ in digestibility experiments with rats.

Another possible source of error is the loss of faecal material during the collecting periods. If, for instance, the mean daily results obtained for pig no. 18 during period $\mathrm{A}$ are considered it may be calculated that to give a $100 \%$ recovery of $\mathrm{Cr}_{2} \mathrm{O}_{3}$ in the faeces there must have been a mean daily loss of $48 \mathrm{~g}$ dry faeces or $218 \mathrm{~g}$ fresh faeces. (The faeces excreted by the pigs in this experiment contained about $22.0 \%$ dry matter.) A loss of this magnitude in a metabolism cage is quite inconceivable. From the digestibility coefficient of dry matter as determined by the conventional method it may also be calculated, assuming $100 \%$ recovery of $\mathrm{Cr}_{2} \mathrm{O}_{3}$, that the mean percentage of $\mathrm{Cr}_{2} \mathrm{O}_{3}$ in the dry matter of the faeces of pig no. 18 during period $\mathrm{A}$ should have been 4.27 . The determined value was $3.6 \mathrm{r}$ and it is significant that the $\mathrm{Cr}_{2} \mathrm{O}_{3}$ content did not attain a value of 4.27 in any of the separate collections of faeces during this period. It is unlikely that there was any loss of faeces of abnormally high $\mathrm{Cr}_{2} \mathrm{O}_{8}$ content as Dansky \& Hill (1952) have suggested to explain low recoveries of $\mathrm{Cr}_{2} \mathrm{O}_{3}$ in experiments with growing chicks on utilization of dry matter. The only possible loss of faeces in Exp. I might have occurred from the overnight collections which in fact invariably contained the lowest percentage of $\mathrm{Cr}_{2} \mathrm{O}_{3}$ in the dry matter.

Schneider (1955) obtained low recoveries of $\mathrm{Cr}_{2} \mathrm{O}_{3}$ in experiments with pigs and considered that loss of $\mathrm{Cr}_{2} \mathrm{O}_{3}$ might have occurred in the preparation of the faeces for analysis. That errors of this type might arise was realized early in this work for it was noticed that after the samples of dried faeces had been ground there was a tendency for very fine particles to settle out from the more fibrous material. It was found that, for a particular sample of faeces, material of small particle size was considerably higher in $\mathrm{Cr}_{2} \mathrm{O}_{3}$ (e.g. $4 \cdot 58 \%$ ) than the coarser faecal material (e.g. $2 \cdot 62 \%$ ). Consequently, each faecal collection was ground in a Wiley mill and the utmost care was taken in sampling the faeces for analysis. It is quite possible that errors of this type might occur in experiments in which small samples are taken for $\mathrm{Cr}_{2} \mathrm{O}_{3}$ analysis from total daily collections of faeces and in which dried faeces are ground in a larger type of mill, as Schneider (1955) in fact discovered.

Though it is difficult to imagine that during the collection periods of Exp. I the excretion of $\mathrm{Cr}_{2} \mathrm{O}_{3}$ in the faeces of pigs nos. $\mathrm{I} 7$ and $\mathrm{r} 8 \mathrm{had}$ not yet reached equilibrium with the intake, there is some evidence from experiments reported in the literature that a preliminary feeding period of 4 days is insufficient to ensure a complete and constant excretion of $\mathrm{Cr}_{2} \mathrm{O}_{3}$. For instance, Pigden \& Brisson (1956), working with 
sheep, found that the length of preliminary period required for the mean daily recovery of $\mathrm{Cr}_{2} \mathrm{O}_{3}$ to equal intake was ro days, although the mean daily recovery reached $90 \% 4$ days after the initial feeding of $\mathrm{Cr}_{2} \mathrm{O}_{3}$ had begun. However, the preliminary period for ruminants would most probably be longer than for pigs and if insufficient time had elapsed for equilibrium to be established in Exp. I it might have been expected that the recovery of $\mathrm{Cr}_{2} \mathrm{O}_{3}$ would have been highest in period $\mathrm{C}$ and lowest in period A. It was certainly not so. Barnicoat (1945) observed a constant low recovery of $\mathrm{Cr}_{2} \mathrm{O}_{3}$ in an experiment with pigs that had received $\mathrm{Cr}_{2} \mathrm{O}_{3}$ in the diet continuously for 7 weeks, and pointed out that it is possible for $\mathrm{Cr}_{2} \mathrm{O}_{3}$ to be retained in the digestive tract of experimental animals. In this connexion it is relevant to draw attention again to the complete recovery of $\mathrm{Cr}_{2} \mathrm{O}_{3}$ obtained in Exp. 3 , but obviously there is a limit to the extent to which retention in the digestive tract can occur.

There would thus seem to be no reasonable explanation of the low recovery of $\mathrm{Cr}_{2} \mathrm{O}_{3}$ obtained in Exp. I. Subsequent (unpublished) experiments have been carried out with pigs in which the diet, technique of feeding, collection and analysis of the faeces have been identical with those now described. Certain of these experiments have led to complete recovery of $\mathrm{Cr}_{2} \mathrm{O}_{3}$ in the faeces but recoveries as low as $75 \%$ have been obtained in others. An observation made in this later work was that low recovery of $\mathrm{Cr}_{3} \mathrm{O}_{2}$ in the faeces was always associated with the use of a particular sample of $\mathrm{Cr}_{2} \mathrm{O}_{3}$. Although all the samples of $\mathrm{Cr}_{2} \mathrm{O}_{3}$ used were apparently identical chemically it was noticed that the $\mathrm{Cr}_{2} \mathrm{O}_{3}$ which gave low faecal recovery was particularly finely divided in contrast to the samples of larger particle size used in experiments in which complete recovery was obtained. The question of faecal recovery of ingested $\mathrm{Cr}_{2} \mathrm{O}_{3}$ would seem to merit re-investigation, and further work is being done in this laboratory.

Although satisfactory recoveries of this index substance have been reported in the literature (Lloyd, Rutherford \& Crampton, 1955; Raymond \& Minson, 1955), this experience, for reasons obscure at present, is by no means universal. The error involved in this loss may be fully realized when the equation relating the true digestion coefficient, the digestion coefficient according to the indicator method, and the percentage loss of the indicator proposed by Mueller (I956) is applied to the results of a number of digestibility trials reported in the literature in which the conventional method is compared with the indicator method. For example, in one of the trials with pigs described by Clawson et al. (1955) the digestibility coefficients of dry matter as determined by the conventional and $\mathrm{Cr}_{2} \mathrm{O}_{3}$-indicator methods were 75 and $7 \mathrm{I} \%$ respectively, a difference which, in fact, was equivalent to a loss of $13.8 \% \mathrm{Cr}_{2} \mathrm{O}_{3}$.

Exp. I illustrated that $\mathrm{Cr}_{2} \mathrm{O}_{3}$, crude protein, crude fibre and $\mathrm{Cr}_{2} \mathrm{O}_{3}$-free ash were excreted in the faeces of pigs in regular daily patterns, which to a certain extent were characteristic for each pig and depended upon the length of time between feeds. An explanation of such diurnal variations in faecal composition may be put forward after the implications of the results of Exp. 2 and 3 have been considered in more detail.

During the first $4 \mathrm{~h}$ of digestion the rate of passage of nitrogenous material from the stomach into the small intestine was obviously much greater than the rate of passage 
of the bulk of dry matter, whereas dry matter as a whole was removed from the stomach at a more rapid rate than crude fibre. It has been shown in this connexion that calcium and phosphorus are dissolved in the gastric juice and removed preferentially from the stomach of the pig (Moore \& Tyler, 1955 $a, b$ ) and from the gizzard of the hen (Tyler, 1946) during the early stages of digestion. On the other hand, Moore (1952) found that dry matter remaining in the stomach of pigs killed 2,4 and $6 \mathrm{~h}$ after feeding contained increasing concentrations of insoluble ash, and the percentage of insoluble ash in the dry matter of the stomach contents was always greater than in the feed. Recent experiments reported by Cooper (1956) showed that the food residues taken from the stomach of pigs $4 \mathrm{~h}$ after feeding were higher in lignin and cellulose than the feed. All this evidence suggests that, during the earlier stages of the digestion process in the pig, material entering the small intestine from the stomach is more highly digestible than that entering the small intestine at a later stage. This suggestion is not inconsistent with the generally accepted views on the mechanism of gastric discharge (Cowgill, 1946). The first food material from a particular meal to pass into the small intestine will consist mainly of that fraction easily extracted from the food mass in the stomach by the gastric juice, either in true or colloidal solution or in suspension if the particles of ingesta are small enough. This fraction will constitute the highly digestible portion of the diet since, owing to the action of salivary amylase, gastric pepsin and hydrochloric acid it will contain relatively large amounts of carbohydrate, protein or protein derivatives, and minerals. As digestion proceeds, this leaching process will gradually subside until the final stages of gastric discharge will be characterized by the passage from the stomach of ingesta of low digestibility owing to their high content of lignin, cellulose and silica.

Diurnal variations in the faecal concentrations of crude protein, minerals and crude fibre would appear therefore to depend largely on the differential rates of passage of these food constituents from the stomach. Faeces high in crude protein and soluble ash would be derived from food material leaving the stomach in the early stages of digestion whereas faeces high in crude fibre would be derived from material leaving the stomach in the later stages.

During the first $4 \mathrm{~h}$ after feeding, the rate of passage of $\mathrm{Cr}_{2} \mathrm{O}_{3}$ from the stomach of the pigs was about the same as that of the total dry matter. It is impossible to predict whether it would be so during the whole digestion period, although it is interesting to note that Fournier (1950) found that the percentage of titanium dioxide, a marker similar to $\mathrm{Cr}_{2} \mathrm{O}_{3}$, in the stomach contents of rats at various stages in the digestion process, was always the same as in the food. Diurnal variations in the $\mathrm{Cr}_{2} \mathrm{O}_{3}$ content of the faeces of the pigs in Exp. I would appear therefore to be caused indirectly by the differential rates of passage of the other food constituents of differing digestibility, high concentrations of $\mathrm{Cr}_{2} \mathrm{O}_{3}$ occurring in the faeces derived from food material of high digestibility and low concentrations of $\mathrm{Cr}_{2} \mathrm{O}_{3}$ occurring in faeces derived from food material of low digestibility. It is not surprising, therefore, that the faecalexcretion curves of $\mathrm{Cr}_{2} \mathrm{O}_{3}$, crude protein and $\mathrm{Cr}_{2} \mathrm{O}_{3}$-free ash obtained in Exp. I were all very similar, but opposite to those obtained for crude fibre. Although the faecalexcretion curves for $\mathrm{Cr}_{2} \mathrm{O}_{3}$-free ash were very similar to those for $\mathrm{Cr}_{2} \mathrm{O}_{3}$, it is to be 
expected that the curves for $\mathrm{Cr}_{2} \mathrm{O}_{3}$-free insoluble ash would be similar to the crudefibre excretion curves.

Although diurnal variations in faecal composition have been discussed mainly in terms of differential rates of passage of the various food constituents from the stomach it is realized that this may not be the whole explanation. For example, different food constituents may possess different rates of passage along the small and large intestines; a proportion of the nitrogen determined in the faeces may have been of endogenous or microbial origin; limited digestion of the crude-fibre fraction may have taken place in the large intestine of the pigs (Vartiovaara \& Roine, 1942) and the extent of this digestion may have depended on the length of time that food residues had remained in the large intestine.

Exp. 2 indicated that when pigs were given at 9.30 a.m. a meal containing $\mathrm{Cr}_{2} \mathrm{O}_{3}$ the residues of the highly digestible fraction of this meal (i.e. high in $\mathrm{Cr}_{2} \mathrm{O}_{3}$ ) were excreted in the faeces about $24 \mathrm{~h}$ later. When the single dose of $\mathrm{Cr}_{2} \mathrm{O}_{3}$ was included in the 3.30 p.m. meal faeces of highest $\mathrm{Cr}_{2} \mathrm{O}_{3}$ content were excreted between 24 and $29 \mathrm{~h}$ later. Attention has already been drawn to the small peaks of $\mathrm{Cr}_{2} \mathrm{O}_{3}$ excretion that occurred in the faeces of pigs nos. 17 and $\mathrm{I} 8$ about $34 \mathrm{~h}$ after the $\mathrm{Cr}_{2} \mathrm{O}_{3}$ had been given in the 9.30 a.m. feed and about $43 \mathrm{~h}$ after the $\mathrm{Cr}_{2} \mathrm{O}_{3}$ had been given in the 3.30 p.m. feed. These subsidiary peaks were most probably due to the fact that small amounts of $\mathrm{Cr}_{2} \mathrm{O}_{3}$ were still present in the stomachs of the pigs when the following meal (containing no $\mathrm{Cr}_{2} \mathrm{O}_{3}$ ) was given. This last remaining $\mathrm{Cr}_{2} \mathrm{O}_{3}$ would then be removed from the stomach with the highly digestible fraction of the following meal.

From the results of Exps. 2 and 3 it is therefore possible to predict that pigs fed at 9.30 a.m. and 3.30 p.m. on a diet containing $\mathrm{Cr}_{2} \mathrm{O}_{3}$ would show each day two peaks of $\mathrm{Cr}_{2} \mathrm{O}_{3}$ excretion in the faeces, one in the morning and the other in the evening, with peaks of crude protein and $\mathrm{Cr}_{2} \mathrm{O}_{3}$-free ash occurring at similar times. Peaks of excretion of crude fibre should also occur twice daily in the faeces low in $\mathrm{Cr}_{2} \mathrm{O}_{3}$. Such was in fact the result obtained with pig no. I 8 during the last 4 days of period $\mathrm{A}$ (Exp. I). During this period, however, only a single daily peak of $\mathrm{Cr}_{2} \mathrm{O}_{3}$, crude protein and $\mathrm{Cr}_{2} \mathrm{O}_{3}$-free ash was observed in the faeces of pig no. 17. The most probable explanation is that during period A pig no. 17 took over an hour to finish each meal whereas pig no. 18 took only I0-I 5 min. Moore (1952) had noted that a considerable proportion of the $9.30 \mathrm{a} . \mathrm{m}$. feed was still present in the stomachs of pigs $6 \mathrm{~h}$ later. It is therefore possible that the highly digestible fraction of the $9.30 \mathrm{a.m}$. meal was still leaving the stomach of pig no. 17 when it ate the 3.30 p.m. meal. As a result the material of high digestibility derived from the 3.30 p.m. meal would be removed from the stomach in preference to the residues of low digestibility derived from the previous 9.30 a.m. meal. Each single daily peak of $\mathrm{Cr}_{2} \mathrm{O}_{3}$, crude protein, $\mathrm{Cr}_{2} \mathrm{O}_{3}$-free ash excreted in the faeces of pig no. $\mathrm{I} 7$ during period $\mathrm{A}$ would thus be derived from both meals of the previous day.

Differences of this nature did not arise in periods B and C (Exp. I) since during these periods pigs nos. $\mathrm{I} 7$ and $\mathrm{I} 8$ consumed each meal at about the same rate and in consequence showed very similar diurnal patterns of faecal excretion for $\mathrm{Cr}_{2} \mathrm{O}_{3}$, crude protein, crude fibre and $\mathrm{Cr}_{2} \mathrm{O}_{3}$-free ash. 
The explanation of the diurnal variations in faecal composition observed with pigs nos. 17 and $\mathrm{I} 8$ during period $\mathrm{A}$ (Exp. I) may be extended also to the diurnal variations obtained under the different feeding treatments of periods B and C. It is perhaps sufficient to point out that an increase in the period of time between feeding (as in period B) should obviously result in an increase in the period of time between the excretion of the two peak concentrations of $\mathrm{Cr}_{2} \mathrm{O}_{3}$ in the faeces. Similarly, during period $\mathrm{C}$, when the pigs were fed three times daily, three peaks of $\mathrm{Cr}_{2} \mathrm{O}_{3}$ could be expected to occur in each daily collection of faeces, as was in fact found.

Reports in the literature of diurnal variations in composition of faeces in the pig are rather limited and are not strictly comparable with those found in the work now described owing to the different techniques of feeding and collection. From a diagram in a paper by Barnicoat (1945) it would appear that the $\mathrm{Cr}_{2} \mathrm{O}_{3}$ concentration in the faeces of a pig fed three times daily (times unspecified) was highest in the early, and lowest in the late, hours of the day. Clawson et al. (1955) collected faeces from selffed pigs at 5.30 a.m., ro.30 a.m., 3.30 p.m. and 8.30 p.m. and noted that the I0.30 a.m. and $8.3 \circ$ p.m. collections were highest and lowest in $\mathrm{Cr}_{2} \mathrm{O}_{3}$ respectively. On the other hand, Schürch (1952) and Schürch, Crampton, Haskell \& Lloyd (1952) could find little difference in the concentration of $\mathrm{Cr}_{2} \mathrm{O}_{3}$ in the bulked morning and bulked evening faeces excreted by pigs on digestion trials.

Diurnal variations in $\mathrm{Cr}_{2} \mathrm{O}_{3}$ excreted in the faeces of ruminants have been described by Kane et al. (1952), Smith \& Reid (1955) and Hardison, Engel, Linkous, Sweeney \& Graf (1956) working with cows, and by Raymond \& Minson (1955) and Pigden \& Brisson (1956) working with sheep. Dansky \& Hill (1952) and Mueller (1956) have reported diurnal variations in the $\mathrm{Cr}_{2} \mathrm{O}_{3}$ content of the droppings of poultry. However, it would seem pointless to attempt to correlate the findings of these workers with those now reported in view of the great differences in the anatomy and physiology of the digestive tracts of pigs, ruminants and birds. Nevertheless, it is interesting that Kane et al. (1952) found that diurnal-excretion curves for $\mathrm{Cr}_{2} \mathrm{O}_{3}$ in the faeces of cows were generally opposite to those obtained for lignin, and it is therefore possible that the factors governing diurnal variation in the composition of the faeces of monogastric animals might also operate to some extent in ruminants.

The effect of diurnal variations in the composition of the faeces of pigs on the determination of the digestibility of dry matter, crude protein and crude fibre will be discussed in a future paper.

\section{SUMMARY}

I. In the first of three experiments a study was made of the diurnal variations in the faecal excretion of $\mathrm{Cr}_{2} \mathrm{O}_{3}$, crude protein and crude fibre by two pigs. In period $\mathrm{A}$ the pigs were fed at 9.30 a.m. and 3.30 p.m., in period $B$ at 7.00 a.m. and 7.00 p.m., and in period $\mathrm{C}$ at 7.00 a.m., I.00 p.m. and 7.00 p.m. After a preliminary period of 4 days on each feeding treatment each voiding was collected for 4 consecutive days.

2. In Exp. I the faecal-excretion pattern of $\mathrm{Cr}_{2} \mathrm{O}_{3}$, crude protein, crude fibre and $\mathrm{Cr}_{2} \mathrm{O}_{3}$-free ash depended on the length of time between feeds and on the number of daily feeds, and to some extent it was characteristic for each pig. 
3. For a particular pig and feeding treatment diurnal variation curves for $\mathrm{Cr}_{2} \mathrm{O}_{3}$, crude protein and $\mathrm{Cr}_{2} \mathrm{O}_{3}$-free ash were very similar but opposite to those obtained for crude fibre.

4. During the 4-day collection periods of Exp. I a mean of $83 \%$ of the ingested $\mathrm{Cr}_{2} \mathrm{O}_{3}$ was recovered in the faeces. Possible causes of the low recovery of $\mathrm{Cr}_{2} \mathrm{O}_{3}$ are discussed.

5. Exp. 2 was performed to determine the faecal excretion pattern of $\mathrm{Cr}_{2} \mathrm{O}_{3}$ when the latter was administered to two pigs in a single dose with either the $9.30 \mathrm{a} . \mathrm{m}$. or 3.30 p.m. feed. When $\mathrm{Cr}_{2} \mathrm{O}_{3}$ was included in the $9.30 \mathrm{a} . \mathrm{m}$. meal it was excreted at highest concentration between $8.00 \mathrm{a} . \mathrm{m}$. and $9.00 \mathrm{a} . \mathrm{m}$. the following day. When included in the 3.30 p.m. meal the $\mathrm{Cr}_{2} \mathrm{O}_{3}$ was excreted between 4.00 p.m. and 8.00 p.m. the following day. It was possible therefore to relate a particular peak of $\mathrm{Cr}_{2} \mathrm{O}_{3}$ excretion in the faeces with the $\mathrm{Cr}_{2} \mathrm{O}_{3}$ derived from a particular meal.

6. In Exp. 3 the different rates of passage of $\mathrm{Cr}_{2} \mathrm{O}_{3}$, crude protein and crude fibre along the digestive tract were investigated. Two pigs were killed $4 \mathrm{~h}$ after they had received a single dose of $\mathrm{Cr}_{2} \mathrm{O}_{3}$ in the morning feed and the contents of each section of the gastro-intestinal tract were analysed.

7. During the early stages of digestion crude protein was found to be removed preferentially from the stomach, whereas crude fibre tended to remain behind in it. Dry matter as a whole appeared to be removed from the stomach at about the same rate as $\mathrm{Cr}_{2} \mathrm{O}_{3}$.

8. Complete recovery of $\mathrm{Cr}_{2} \mathrm{O}_{3}$ was obtained from the gastro-intestinal contents of the pigs in this experiment.

9. An explanation based on the differential rates of passage of food constituents from the stomach of the pig is offered to account for the observed diurnal variations in faecal composition.

The author wishes to acknowledge with thanks the assistance in these experiments of Mr R. M. Loosmore, Dr D. A. Balch, Mr T. Pearson and Miss E. D. Rolls.

\section{REFERENCES}

Anderson, A. C. \& Winther, J. E. (1934). Beretn. Forsøgslab. Kbh. no. I 55, p. I 17.

Association of Official Agricultural Chemists (1950). Official and Tentative Methods of Analysis. 7 th ed. Washington, D.C.: Association of Official Agricultural Chemists.

Barnicoat, C. R. (1945). N.Z. F. Sci. Tech. A, 27, 202.

Boyne, A. W., Campbell, R. M., Davidson, J. \& Cuthbertson, D. P. (1956). Brit. F. Nutr. 10, 325. Christian, K. R. \& Coup, M. R. (1954). N.Z. F. Sci. Tech. A, 36, 328.

Clawson, A. J., Reid, J. T., Sheffy, B. E. \& Willman, J. P. (1955). \%. Anim. Sci. 14, 700.

Cooper, P. H. (1956). Some effects of bran and cellulose on the water relationships in the digesta and faeces of pigs. Ph.D. Thesis, University of Reading.

Cowgill, G. R. (1946). In Howell's Textbook of Physiology, I 5 th ed. [J. F. Fulton, editor.] Philadelphia: W. B. Saunders.

Dansky, L. M. \& Hill, F. W. (1952). F. Nutr. 47, 449.

Fournier, P. (1950). C.R. Acad. Sci., Paris, 231, 1343.

Hardison, W. A., Engel, R. W., Linkous, W. N., Sweeney, H. C. \& Graf, G. C. (1956). J. Nutr. 58, i I. Heller, V. G., Breedlove, C. H. \& Likely, W. (1928). F. biol. Chem. 79, 275.

Kane, E. A., Jacobson, W. C. \& Moore, L. A. (I952). J. Nutr. 47, 263.

Kreula, M. S. (1947). Biochem. F. 41, 269.

Lloyd, L. E., Rutherford, B. E. \& Crampton, E. W. (1955). F. Nutr. 56, 265.

Moore, J. H. (1952). The absorption and excretion of minerals by pigs. Ph.D. Thesis, University of Reading. 
Moore, J. H. \& Tyler, C. (1955a). Brit. F. Nutr. 9,63.

Moore, J. H. \& Tyler, C. (1955b). Brit. $¥$. Nutr. 9, 8 r.

Moore, J. H. \& Tyler, C. (1955c). Brit. F. Nutr. 9, 389.

Mueller, W. J. (I956). F. Nutr. 58, 29.

Pigden, W. J. \& Brisson, G. J. (1956). Canad. F. agric. Sci. 36, I46.

Raymond, W. F. \& Minson, D. J. (1955). F. Brit. Grassl. Soc. 10, 282.

Schneider, W. (r955). Z. Tierernähr. 10, 269.

Schürch, A. (1952). Mitt. Lebensm. Hyg., Bern, 43, 335 .

Schürch, A. F., Crampton, E. W., Haskell, S. R. \& Lloyd, L. E. (1952). F. Anim. Sci. r1, 26 r.

Smith, A. M. \& Reid, J. T. (1955). F. Dairy Sci. 38, 5 I 5 .

Tyler, C. (1946). F. agric. Sci. 36, 275.

Vartiovaara, U. \& Roine, P. (1942). Maataloust. Aikakausk. 14, 127.

\title{
Volatile fatty acids and lactic acid in the rumen of dairy cows receiving a variety of diets
}

\author{
By D. A. BALCH* aND S. J. ROWLAND \\ National Institute for Research in Dairying, University of Reading \\ (Received 2 I December 1956)
}

It has been known for many years that organic acids are produced by bacterial fermentation in the rumen. The importance of such fermentation in the nutrition of the ruminant has been adequately appreciated only recently, with the establishment of the relative proportions in which the acids are produced and the discovery of their role in ruminant metabolism.

Elsden (r945) showed that the production of a mixture of acetic and propionic acids, a butyric isomer and traces of a valeric isomer was characteristic of fermentation in the sheep's rumen. Acetic acid was present in greatest amount and the proportion of propionic acid usually exceeded that of butyric. Ample confirmation with a wide variety of diets has since been obtained by Elsden, Hitchcock, Marshall \& Phillipson (1946), Schambye \& Phillipson (r949), Gray, Pilgrim \& Weller (1951), Kiddle, Marshall \& Phillipson (195I), Gray, Pilgrim, Rodda \& Weller (1952) and El-Shazly (1952). Gray \& Pilgrim (I95I) reported that as the concentration of total volatile fatty acids in the rumen increased, there was a decrease in the ratio of acetic to propionic acid. A similar difference was shown in the experiments of El-Shazly (1952) between the samples taken before and after feeding, but not in those of Schambye \& Phillipson (I949). When diets containing high proportions of flaked maize were fed to lambs by Phillipson (1952), high and sustained concentrations of lactic acid were observed and the ratio of acetic to propionic acid was unusually low. Previously, lactic acid had been found in high concentration only shortly after the feeding of high-sugar diets (Phillipson, 1942; Phillipson \& McAnally, 1942), the lactic acid disappearing rapidly.

A few values for steers given by Elsden (1945) and Elsden et al. (1946) indicated

* Present address : Department of Agricultural Chemistry, University of Reading. 